\title{
A climatological study of rural surface ozone in central Greece
}

\author{
P. D. Kalabokas and C. C. Repapis \\ Academy of Athens, Research Center for Atmospheric Physics and Climatology, Athens, Greece \\ Received: 4 February 2003 - Published in Atmos. Chem. Phys. Discuss.: 7 October 2003 \\ Revised: 11 June 2004 - Accepted: 16 June 2004 - Published: 13 July 2004
}

\begin{abstract}
Recent studies show that surface ozone levels at rural sites in Greece are generally high when compared with rural ozone measurements at northern European sites. The area of SE Europe, including Greece, is not very well monitored regarding rural ozone in comparison to central and northern Europe. In order to have the best possible picture of the rural surface ozone climatology in the area, based on the available data-sets of long-term continuous monitoring stations, the 10-year measurement records (1987-1996) of the Athens peripheral station of Liossia, $(12 \mathrm{~km} \mathrm{~N}$ of the city center) and the urban background station of Geoponiki (3 $\mathrm{km} \mathrm{W})$ as well as the 4-year record (1996-1999) of the rural station of Aliartos (100 km NW of Athens), are analyzed in this paper. The data for Liossia and Geoponiki stations are screened for cases of strong airflow from rural areas $(\mathrm{N}-$ $\mathrm{NE}$ winds stronger than $5 \mathrm{~m} / \mathrm{s}$ ). The variation characteristics of the average rural ozone afternoon levels (12:00-18:00), with the best vertical atmospheric mixing, are mainly examined since these measurements are expected to be representative of the broader area. In all three stations there is a characteristic seasonal variation of rural ozone concentrations with lowest winter afternoon values at about $50 \mu \mathrm{g} / \mathrm{m}^{3}$ in December-January and average summer afternoon values at about $120 \mu \mathrm{g} / \mathrm{m}^{3}$ in July-August, indicating that high summer values are observed all over the area. The rural summer afternoon ozone values are very well correlated between the three stations, implying spatial homogeneity all over the area but also temporal homogeneity, since during the 13-year period 1987-1999 the rural afternoon ozone levels remained almost constant around the value of $120 \mu \mathrm{g} / \mathrm{m}^{3}$.
\end{abstract}

Correspondence to: P. D. Kalabokas

(phatmcli@otenet.gr)

\section{Introduction}

Atmospheric ozone plays an important role in the physicochemical processes of the troposphere but it has also strong oxidant properties, which at certain ambient concentration levels may cause damages to humans, animals and vegetation (Finlayson-Pitts and Pitts, 1997; Bates, 1994). The problem of tropospheric ozone has changed dimensions about fifteen years ago, when it was realized that increased surface ozone is not only a local urban problem as an almost global increase of surface rural ozone concentrations, especially in the northern hemisphere, has been observed during the 20th century, which is attributed primarily to photochemical production (Volz and Kley, 1988). In central and northern Europe there are many rural air pollution stations, providing a satisfactory picture of the spatial distribution of surface ozone concentrations but there are only a few systematic measurements covering the Mediterranean basin and especially its eastern part (Beck and Grennfeld, 1994; Scheel et al., 1997). The high levels of solar irradiation observed in the Mediterranean, in combination with the emitted anthropogenic and biogenic ozone precursors, might favor photochemical ozone production. High surface ozone values have been already reported at western and central Mediterranean sites in Italy and Spain (Millan et al., 1992; Bonasoni et al., 2000). Concerning the eastern Mediterranean, several intensive shortterm measurements including aircraft flights have been carried out in Greece, around the urban area of Athens and over the Aegean Sea during the past decade, which recorded high surface ozone values (Kallos, 1995; Ziomas, 1998; PAUR report, 1998; Kourtidis et al., 2002; Kouvarakis et al., 2002; Traub et al., 2003; Roelofs et al., 2003). In Greece, few systematic rural ozone measurements outside the greater Athens area have been published so far covering time-periods of several months to 2-3 years (Kourtidis et al., 1996; Glavas, 1999; Kouvarakis et al., 2000). In previous works efforts have taken place to extract the information about rural ozone 


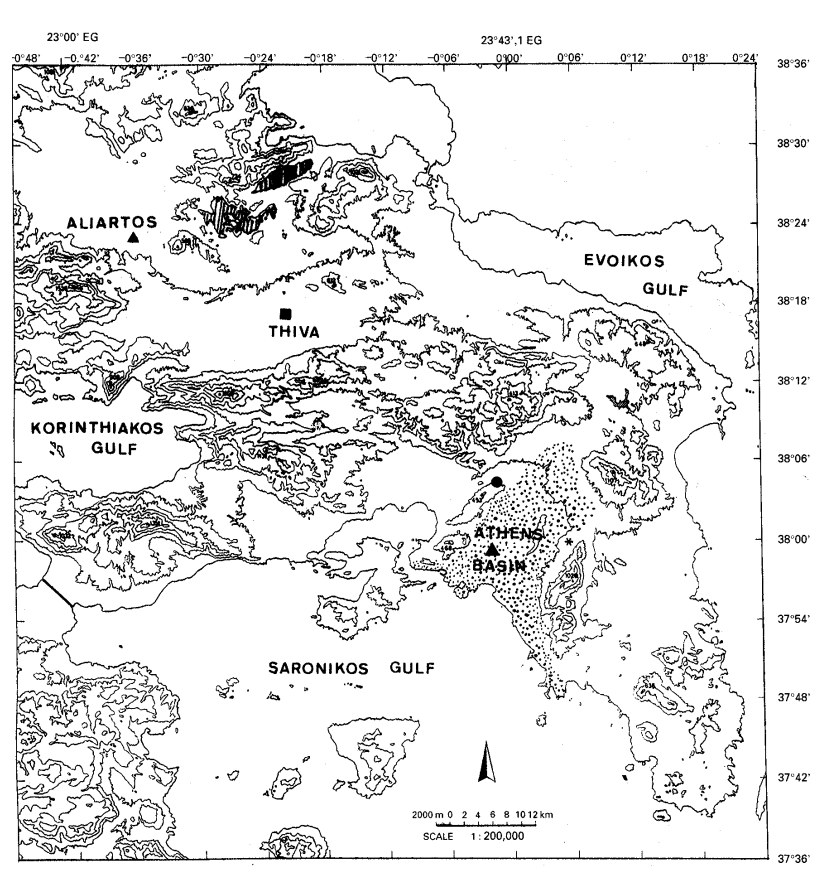

Fig. 1. Map of the area including the rural station of Aliartos and the Athens basin with elevation contours at $200 \mathrm{~m}$ intervals. The locations of the Liossia and Geoponiki stations in the Athens basin are marked with a black cycle and a triangle respectively. Residential areas are indicated by stippling.

levels around the city of Athens based on the measurements of the Athens urban peripheral stations. The analysis of several years ozone records show that the rural ozone levels surrounding the Athens basin are significantly higher than values in northern Europe and the Atlantic ocean (Kalabokas et al., 1996; Kalabokas and Bartzis, 1998; Kalabokas et al., 2000; Kalabokas, 2001). In this work, in order to have the best possible picture of the rural surface ozone climatology in the area, based on the available data-sets of long-term continuous monitoring stations, the 10 -year measurement records of the rural ozone values obtained at an Athens peripheral station, an urban background station and a rural station located about $100 \mathrm{~km} \mathrm{NW}$ (4-year record), are systematically analysed. The diurnal, seasonal and interannual rural ozone variations in the area were examined.

\section{Methodology}

The analysis is mainly based on the following surface ozone records: a) the continuous 4-year (1996-1999) data-set of the rural station of Aliartos located about $100 \mathrm{~km} \mathrm{NW}$ of Athens (Fig. 1), b) the 10-year ozone record (1987-1996) of the peripheral station of Liossia, located at the northern edge of the urban agglomeration (12 km from the city center) and c) the 10-year ozone record (1987-1996) of the urban background station of Geoponiki ( $3 \mathrm{~km}$ west of the city center).
The data of the last two stations (Liossia and Geoponiki) were screened for cases of strong airflow from rural areas. For this purpose only measurements under strong northerly winds (NNW to ENE) with daily mean value greater than $5 \mathrm{~m} / \mathrm{s}$, were retained for further processing. The strong northern synoptic flow is very frequent in the area during summer and in that case the station of Liossia is located upwind of the urban area. This is a result of a combination of the highpressure system over the Balkan peninsula and the low pressure system over the middle-east. The resulting winds, called "Etesians" (annual) winds, affect most of the area covered by the Aegean Sea (Repapis et al., 1977).

The rural station of Aliartos is located in the Copais plain, at an altitude of $110 \mathrm{~m}$ above sea level. Continuous ozone measurements started in 1996. The station is operated by the Ministry of the Environment to monitor background pollution (EMEP project). In addition to the continuous ozone measurements in Aliartos there is also a several year record of manual measurements of nitrogen dioxide on a 24-hour basis measured by a wet chemical method (MinEnv report, 2000). The ozone measurements are made by a commercial analyser and average values are recorded every hour. Between Athens and Aliartos there is a topographic barrier composed of several mountains (Fig. 1) and the SE winds which could possibly transport polluted air from Athens to Aliartos are very rare.

The station in Liossia, where the highest ozone values in the Athens network are recorded, is operated by the Ministry of the Environment and has monitored ozone continuously since 1987 until 1997, when the Ministry of the Environment was obliged to relocate the station. In this work the complete ozone data-set obtained during the 10 years of operation (1987-1996) is examined. The station of Geoponiki is also operated by the Ministry of the Environment and has monitored ozone continuously since 1987 . This station is located at the campus of the Agricultural University of Athens and it is not influenced from direct $\mathrm{NO}_{\mathrm{x}}$ emissions of car exhausts in its vicinity and therefore can be considered as an urban background station. The same 10-year period record (1987-1996) of ozone and $\mathrm{NO}_{\mathrm{x}}$ measurements was examined for Geoponiki and for Liossia. The ozone and $\mathrm{NO}_{\mathrm{x}}$ measurements at both Athens stations, are made by using automatic commercial analysers and the values are recorded every one hour.

\section{Results}

In Fig. 2 the average monthly values of rural ozone at Aliartos for the examined 4-year period (1996-1999) are presented, showing a characteristic seasonal variation with summer values being almost double (at $75 \mu \mathrm{g} / \mathrm{m}^{3}$ ) than winter concentrations. The seasonal variation of the daily mean ozone 75th percentiles are also shown, which, from May to August, remain constant at $85 \mu \mathrm{g} / \mathrm{m}^{3}$. The daily 


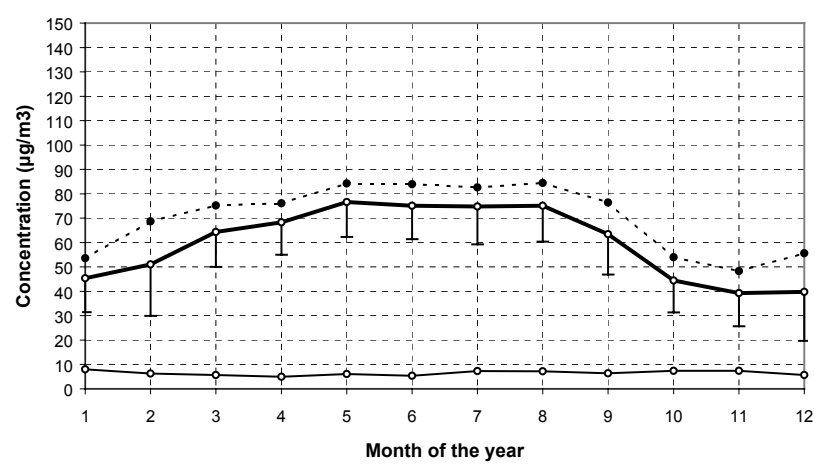

Fig. 2. Seasonal variation of average (bold line), 75th percentile (dashed line) ozone and daily mean $\mathrm{NO}_{2}$ (solid line) at Aliartos for 1996-1999.

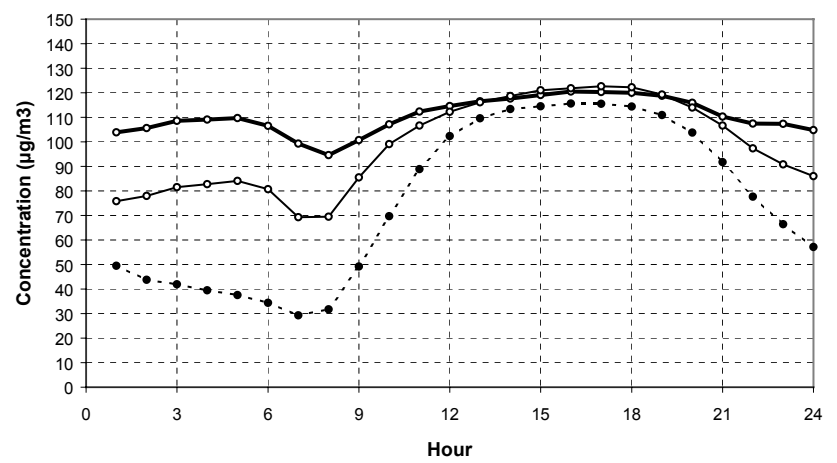

Fig. 3. Diurnal variation for July-August rural ozone at Aliartos (dashed line, 1996-1999), Liossia (bold line) and Geoponiki (solid line) for 1987-1996 (only days with north winds and average daily wind speeds $>5 \mathrm{~m} / \mathrm{s}$ were included for the last two stations).

average $\mathrm{NO}_{2}$ levels (measured as 24-hour averages) at Aliartos remain constant throughout the year at low levels, about $5 \mu \mathrm{g} / \mathrm{m}^{3}$, which is typical for other rural European sites (Beck and Grennfeld, 1994; Scheel et al., 1997).

Because of the fact that the summer period is the most important for surface ozone production, the diurnal ozone profile of the rural station of Aliartos together with the profiles of the Athens peripheral station of Liossia and the urban background station of Geoponiki for the typical summer months of July and August are presented in Fig. 3. A strong diurnal variation is observed for Aliartos, with the afternoon values being almost 3 times higher than the nocturnal ones. This sharp contrast of ozone between day and night in Aliartos is likely to be attributed almost exclusively to physical processes (ozone destruction by dry deposition enhanced by the nocturnal inversion), because the influence of the chemistry is expected to be minimal as the nitrogen oxides concentrations at the site are low in order to destroy sufficient ozone quantities (Fig. 2). Despite the important differences in the nocturnal levels there is a very good agree-

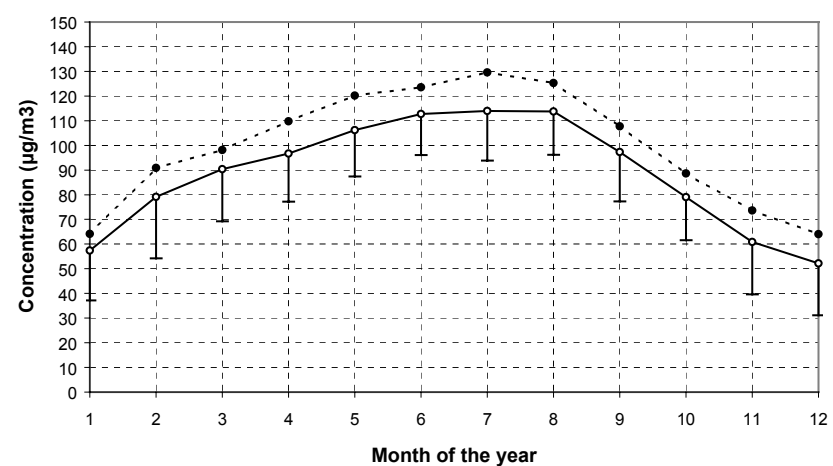

Fig. 4. Seasonal variation of $6 \mathrm{~h}$ rural afternoon (12:00-18:00) average (solid line) and 75 percentile (dashed line) ozone at Aliartos for 1996-1999.

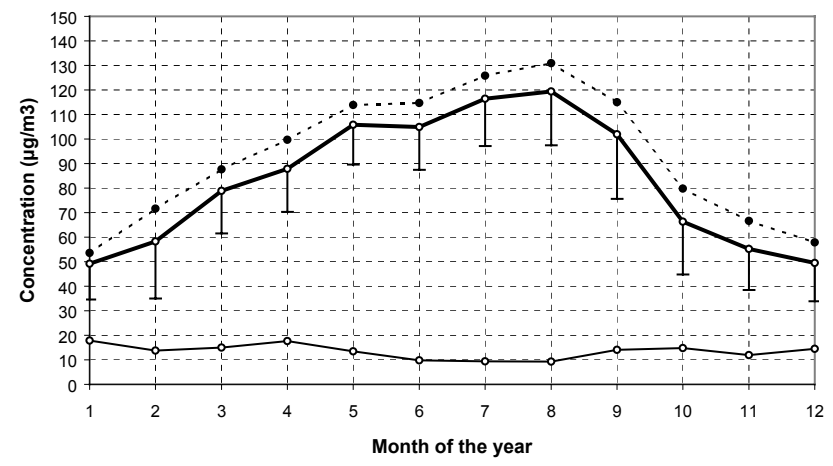

Fig. 5. Seasonal variation of $6 \mathrm{~h}$ rural afternoon (12:00-18:00) ozone average (bold line), 75th percentile (dashed line) and average $\mathrm{NO}_{2}$ (solid line) at Liossia for 1987-1996 (only days with north winds and average daily wind speeds $>5 \mathrm{~m} / \mathrm{s}$ were included).

ment of ozone in the afternoon levels (12:00-18:00) in all stations, especially between Geoponiki and Liossia, which dispose exactly the same 10 -year measurement record. This time-period of the day exhibits the best vertical mixing of air masses in the boundary layer and also the maximum photochemistry. Due to the similar levels of the rural afternoon (12:00-18:00) ozone values combined with the fact that the maximum daily values appear during this time-period, a climatological examination of the average ozone values of this period of the day in the three stations is performed in the following Figs. 4, 5 and 6.

For the rural station of Aliartos, the seasonal variation of the July-August ozone afternoon levels is presented in Fig. 4. The shape of the seasonal variation curve of the afternoon values is similar with that of the daily average values (Fig. 2) but the concentrations range at significantly higher levels ( $55 \mu \mathrm{g} / \mathrm{m}^{3}$ in winter to $120 \mu \mathrm{g} / \mathrm{m}^{3}$ in summer). It is also remarkable that from April to September the 75percentiles exceed the $110 \mu \mathrm{g} / \mathrm{m}^{3}$ level, which is the EU standard for human health protection (EU Directive 92/72/EEC). 


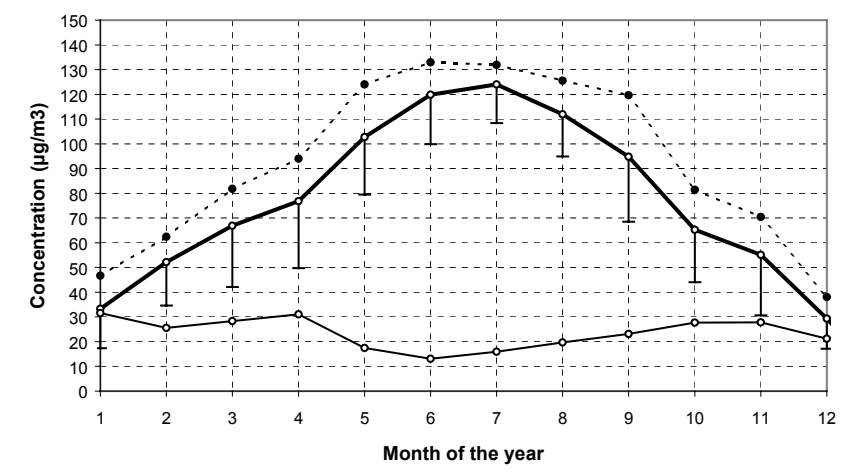

Fig. 6. Seasonal variation of $6 \mathrm{~h}$ rural afternoon (12:00-18:00) ozone average (bold line), 75th percentile (dashed line) and average $\mathrm{NO}_{2}$ (solid line) at Geoponiki for 1987-1996 (only days with north winds and average daily wind speeds $>5 \mathrm{~m} / \mathrm{s}$ were included).

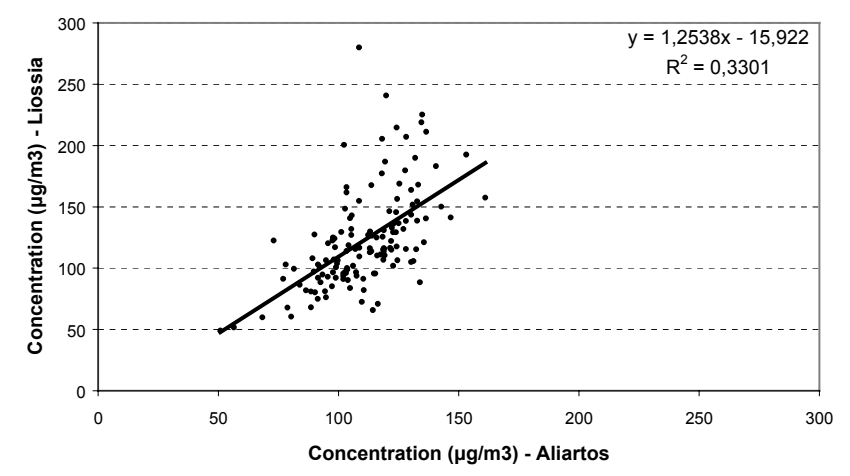

Fig. 7. Correlation of $6 \mathrm{~h}$ average rural afternoon ozone levels (12:00-18:00) of the warm period (April-September) 1996 between Aliartos and Liossia.

Figures 5 and 6 show the seasonal variation of the rural afternoon ozone (12:00-18:00) measurements at Liossia and Geoponiki respectively (only observations for days with values selected under strong northerly winds), which in general seems to be similar with the corresponding rural ozone seasonal curve at Aliartos (Fig. 4). The rural ozone seasonal variation at Liossia shows a minor maximum in May and a major maximum in August, while at Geoponiki there is a summer maximum in July. Nevertheless these little differences do not affect the general outlook of good correlations between the seasonal variation curves in all three stations. The average rural ozone levels in July and August in both Athens stations exceed the EU health protection standard (110 $\mu \mathrm{g} / \mathrm{m}^{3}, 8$-hour average), like in Aliartos. It has to be added also that especially for July and August with the highest frequency of strong northerly winds, the summer afternoon $\mathrm{O}_{\mathrm{x}}$ levels (Kley et al., 1994) are equivalent at both Athens stations Geoponiki and Liossia (Figs. 5 and 6).

In order to have a better picture of the spatial homogeneity of rural afternoon ozone, a more detailed investigation on a daily basis has been carried out based on the year 1996,

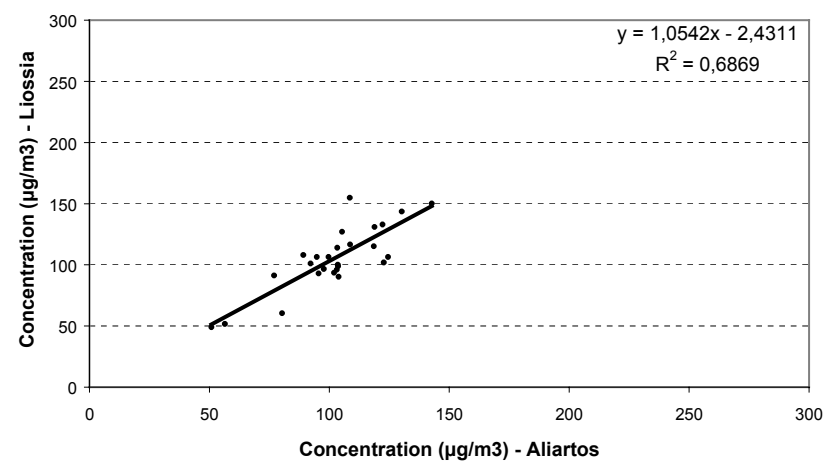

Fig. 8. Correlation of $6 \mathrm{~h}$ average rural afternoon ozone levels (12:00-18:00) of the warm period (April-September) 1996 between Aliartos and Liossia under strong winds (WS $>5 \mathrm{~m} / \mathrm{s}$ ).

the common year of operation for all three stations. The 6hour mean rural afternoon (12:00-18:00) ozone values of the warm period of the year (April-September) of the rural station of Aliartos have been correlated with the corresponding ozone values at the two Athens stations. In Fig. 7 the scatterplot diagram of the 6-hour average rural afternoon (12:0018:00) ozone levels of the period April-September 1996 between Aliartos and Liossia (urban peripheral) are presented (all days were included). As shown the correlation is not good especially in the region of high values. The highest values at Aliartos are around $150 \mu \mathrm{g} / \mathrm{m}^{3}$ while at Liossia are approaching $300 \mu \mathrm{g} / \mathrm{m}^{3}$, which is due to the influence of the urban area, when the site is downwind of Athens. As a result the correlation is not very strong $\left(\mathrm{R}^{2}=0.33\right)$. If only the days with strong winds $>5 \mathrm{~m} / \mathrm{s}$ in the Athens basin are taken into account (Fig. 8), then the shape of the scatter plot diagram changes significantly. The range of values in both stations becomes exactly the same, and the correlation improves significantly $\left(R^{2}=0.69\right)$. The above observation means that the rural ozone values are quite uniform in the area and that under selected meteorological conditions (strong northerly winds) the rural ozone levels of the area surrounding Athens can be monitored at the peripheral station of Liossia. Very similar findings are observed if a correlation between the urban background station of Geoponiki and the rural station of Aliartos is attempted. If all values are taken into account (Fig. 9) the poor correlation $\left(R^{2}=0.37\right)$ is equivalent with that between Liossia and Aliartos (Fig. 7). In the case of strong winds (Fig. 10) the significantly improved correlation coincides exactly $\left(\mathrm{R}^{2}=0.69\right)$ with the corresponding one between Liossia and Aliartos (Fig. 8), which clearly reinforces the above remarks about the uniformity of rural ozone values in the area and indicating that under strong northerly winds the rural ozone levels can be monitored by these two stations in the Athens basin, since they give comparable results with the rural station of Aliartos.

Based on the results of the previous paragraph, an examination of the evolution of the rural ozone levels in the 


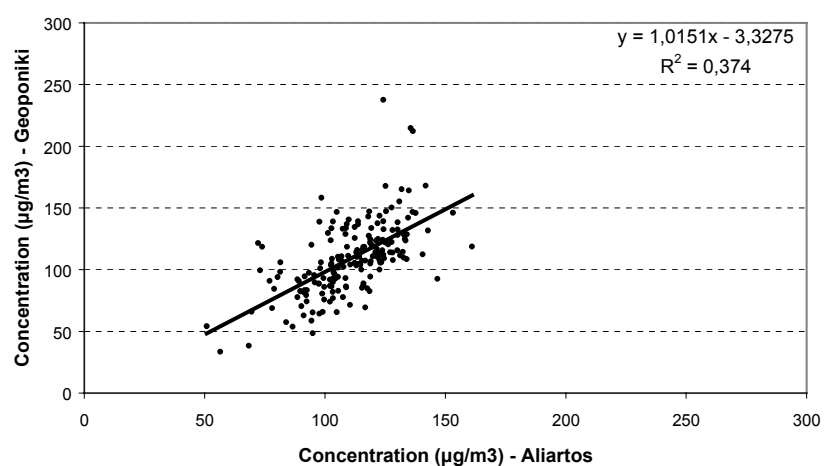

Fig. 9. Correlation of $6 \mathrm{~h}$ average rural afternoon ozone levels (12:00-18:00) of the warm period (April-September) 1996 between Aliartos and Geoponiki.

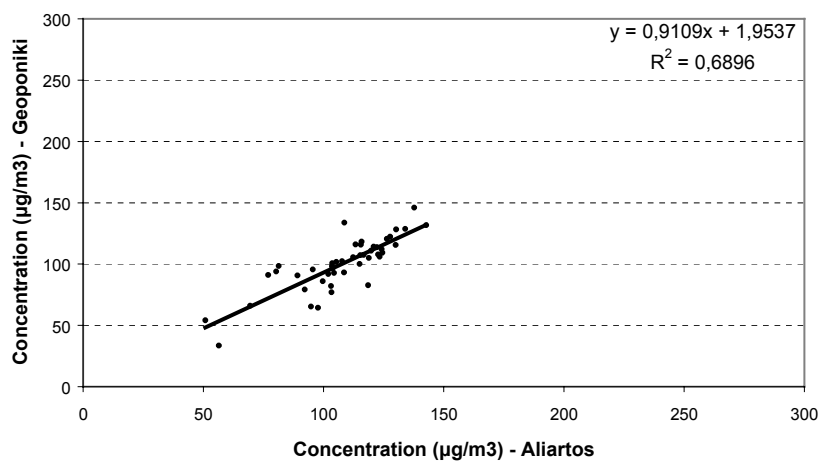

Fig. 10. Correlation of $6 \mathrm{~h}$ average rural afternoon ozone levels (12:00-18:00) of the warm period (April-September) 1996 between Aliartos and Geoponiki under strong winds (WS $>5 \mathrm{~m} / \mathrm{s}$ ).

area during the 13-year period (1987-1999) is attempted. It must be reminded that the first systematic long-term measurements of ozone in Greece started in the Athens basin in 1987. It seems that the situation remained practically unchanged during the afternoon hours in July-August, which is the most important period regarding the violations of the air quality standards. It comes out that the rural afternoon concentrations for July-August remain around $120 \mu \mathrm{g} / \mathrm{m}^{3}$ in the three examined stations (Fig. 11) during the 13-year period, when 3 or 4-year ozone averages are taken in order to smooth the year to year meteorological variability.

In Fig. 12 the diurnal variations of the urban (under south winds) and rural (under strong north winds) ozone at Liossia and Geoponiki are presented for July, the typical summer month. The ozone diurnal course of these two sectors shows different characteristics. At first, the diurnal variation is much more intense for the urban ozone than for the rural, which reflects the differences of the ozone produced in-situ being significantly greater in the case of urban ozone. Another difference is that the maximum in the urban ozone di-

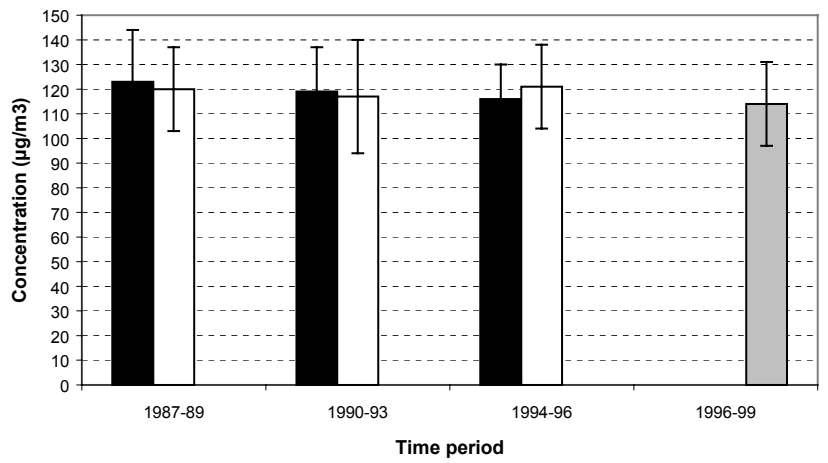

Fig. 11. Evolution of July-August rural afternoon (12:00-18:00) ozone levels at Aliartos (gray), Liossia (black) and Geoponiki (white) for 1987-1999 (only days with north winds and WS $>5 \mathrm{~m} / \mathrm{s}$ were considered for the last two stations).

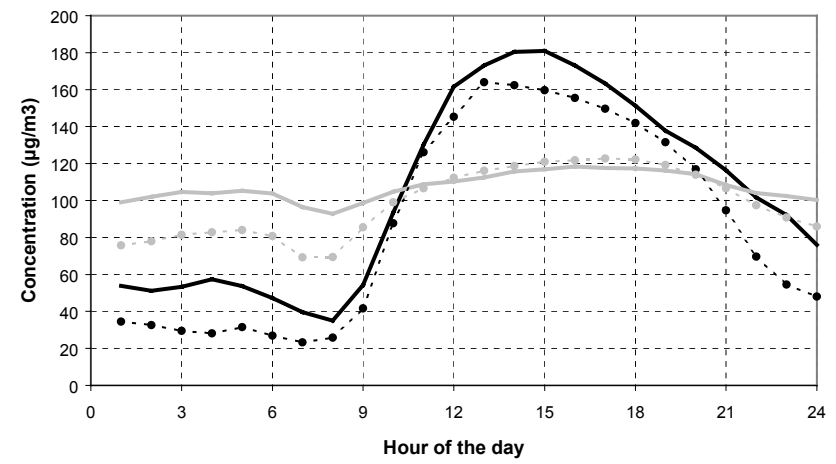

Fig. 12. Diurnal variation for July of the urban (south winds, black) and rural (strong north winds, gray) ozone in Athens for 1987-1996 (Liossia: solid line. Geoponiki: dashed line).

urnal curve occurs at 13:00 in Geoponiki and at 14:00-15:00 in Liossia while the rural ozone diurnal maximum occurs at 17:00 in both stations. From the population exposure point of view it is remarkable to observe that the 10-year climatological average of urban ozone for the hours 14:00-15:00 at $12 \mathrm{~km}$ downwind of Athens (at Liossia) is greater than the $180 \mu \mathrm{g} / \mathrm{m}^{3}$ EU population warning threshold. For the urban background station of Geoponiki the diurnal July maximum is about $165 \mu \mathrm{g} / \mathrm{m}^{3}$ and occurs $1-2 \mathrm{~h}$ earlier than in Liossia. This difference can be explained by the fact that Geoponiki lies about half way from the coast than Liossia (Fig. 1) and the available time for photochemical reactions in the air mass arriving at the site is shorter. The development of sea breeze under weak pressure patterns as southern circulation in July occurs for about $25 \%$ of the time and is associated with high pollution levels. It must be finally added that in Athens during the months of July and August there is almost always sunny weather. The 14-year (1984-1997) average of monthly sunshine duration in Athens is $373 \pm 4 \mathrm{~h}$ and $351 \pm 5 \mathrm{~h}$ for July and August respectively corresponding to $12 \mathrm{~h}$ (July) and $11.3 \mathrm{~h}$ (August) daily sunshine duration. 


\section{Discussion}

The average monthly concentrations of rural ozone and $\mathrm{NO}_{2}$ at Aliartos (Fig. 2) as well as their seasonal variation pattern seem to be similar with results obtained at central European stations. The characteristic of the high summer values being at the same level with the spring maximum is an indication that the photochemical production of ozone on regional scale, following the emissions of the man-made ozone precursors, is the determining factor in the tropospheric ozone budget.

As observed in Fig. 3 there is a different diurnal variation between the rural ozone values at Aliartos and the rural ozone values at Liossia. This reflects the different site characteristics influencing the nocturnal physical ozone destruction to the ground. Aliartos is located in a plain where strong night inversions are observed. On the other hand Liossia is at $210 \mathrm{~m}$ altitude a.s.l. on a mountain slope and most of the time is not influenced by the surface layer. Furthermore at Liossia only days with strong winds are considered, which facilitate the vertical mixing in combination with the local topography. The ozone depletion at night is attributed almost exclusively to physical processes as the influence of the chemistry is expected to be minimal. The reason for that is that nitrogen oxides at the site do not have concentrations high enough in order to influence the ozone curve as the mean monthly values of the 24-hour averages of $\mathrm{NO}_{2}$ is throughout the year about $5 \mu \mathrm{g} / \mathrm{m}^{3}$ (Fig. 2). Therefore, the basic reason of the low night values in Aliartos is the physical destruction of ozone by dry deposition enhanced by the nocturnal inversion. On the other hand in the urban background station of Geoponiki, which is located at the Athens plain, the nocturnal $\mathrm{NO}_{\mathrm{x}}$ concentrations are higher than Liossia (Kalabokas et al., 1999a), as a result of ozone destruction from fresh NO emissions. Consequently the ozone nocturnal levels at Geoponiki are lower than at Liossia as shown in Fig. 3.

Despite the lower average ozone values at Aliartos and the distance $(100 \mathrm{~km})$ between Aliartos and Liossia, there is a good agreement of the observed levels if only the afternoon values (12:00-18:00, period with the best vertical mixing and the maximum photochemistry) are compared. In fact, in both stations there is a clear seasonal variation of the mixing ratios of rural ozone with high average summer afternoon values, greater than $120 \mu \mathrm{g} / \mathrm{m}^{3}$ in August, and low winter afternoon values about $50 \mu \mathrm{g} / \mathrm{m}^{3}$ in December-January. This implies that high summer values are a general characteristic of the examined area. The important secondary summer rural ozone maximum, in contrast to the very frequently observed in most northern European stations spring maximum (Scheel et al., 1997), enhances the hypothesis of the longrange photochemical ozone production and transport during summer, indicating a transboundary pollution problem. The summer maximum at Liossia seems much more pronounced than in Aliartos but this could be attributed to the limits of the screening process at Liossia. The May and June values were extracted from fewer days than the corresponding values of July and August due to the different distribution of strong northerly winds, which are more frequent in late summer (Repapis et al., 1977). It must be reminded that for the averages in Aliartos all values were included, which leads to smoother seasonal variation curves.

It is remarkable that in rural air the EU standard for human health protection $\left(110 \mu \mathrm{g} / \mathrm{m}^{3}, 8\right.$-hour average) can be frequently exceeded during almost all the warm period of the year, (the 6-month period from April to September) at noon and afternoon hours at both stations. The 75-percentile of rural afternoon ozone during these months is almost always higher than $110 \mu \mathrm{g} / \mathrm{m}^{3}$ and from May to August higher than $120 \mu \mathrm{g} / \mathrm{m}^{3}$, which means that the level of 110 and $120 \mu \mathrm{g} / \mathrm{m}^{3}$ are exceeded during at least $25 \%$ of the days for the respective time-periods. The situation regarding the vegetation protection is even worse if the usual standard of AOT40 $10000 \mathrm{ppb}^{*} \mathrm{~h}$ (accumulation of the hours times the ppb exceeding the value 40), for a 6 month growing season, is considered (PORG report, 1997). In fact only during winter months the ozone levels do not exceed $40 \mathrm{ppb}\left(80 \mu \mathrm{g} / \mathrm{m}^{3}\right)$ while from March to September during daytime this value is constantly exceeded. Therefore, serious violations are observed regarding the vegetation protection standard for forests. If an approximate estimation of the exposure is performed, it comes out that the vegetation protection level is exceeded in Aliartos by a factor of 2 and at Liossia by a factor of 3 . The above analysis raise questions on the subject of health risks caused to the population due to the exposure to the surface ozone as well as to damages in vegetation and materials. As mentioned in the introduction ozone is a toxic gas, which if enters the respiratory track in sufficient quantities will cause damage. It may also affect plant growth, crop yield and tree physiology (Bates, 1994).

The problem of population health hazards due to ozone exposure is becoming worse if the ozone concentration levels within the Athens urban plume are examined. In fact constantly high levels of ozone are observed under such conditions, which violate systematically the European Union air pollution standard (Kalabokas et al., 1999b). The summer ozone concentrations at the peripheral Athens stations influenced by the urban plume reach on the average the 170$\mu \mathrm{g} / \mathrm{m}^{3}$ level in the afternoon (Kalabokas et al., 2000). It is surprising though that $10-12 \mathrm{~km}$ downwind of such a dense urban area like Athens under strong sunshine and high ozone precursor emissions the surface ozone increases on the average by only $40 \%$ of its background level, which means that the rural ozone concentrations are on the average the larger contributors of the surface ozone levels even in the periphery of Athens, where the maximum ozone values of the entire urban area are usually observed. On the other hand it should be emphasized that the distribution of the ozone concentrations in an urban plume is quite different than that of the rural ozone. At the peripheral stations downwind of the city the $180 \mu \mathrm{g} / \mathrm{m}^{3}$ hourly standard of population warning (EU 
Directive 92/72/EEC) is relatively often exceeded in summer and the $360 \mu \mathrm{g} / \mathrm{m}^{3}$ hourly standard of alert could be reached (Ziomas et al., 1998; Kalabokas and Bartzis, 1998). For example in 1996, if all over the year ozone measurements are considered, the 8-hour $110 \mu \mathrm{g} / \mathrm{m}^{3}$ EU health standard was exceeded for about $30 \%$ of the days but also about $2 \%$ of the hourly values were higher than the $180 \mu \mathrm{g} / \mathrm{m}^{3}$ EU population warning threshold, which is not observed in rural ozone records. Therefore, the development of photochemical pollution abatement measures is necessary. Nevertheless, all the above observations related with the presence of high ozone background raise questions about the effectiveness of such local actions.

There are other measurements also showing that the high ozone levels are spread all over the area like the data-set of the Athens peripheral Demokritos station (Kalabokas et al., 1996; Kalabokas et al., 2000), which operated for a research study for three years (1992-1995). Similar results were obtained during short-term intensive measuring campaigns over the Aegean Sea (MEDCAPHOT-TRACE campaign in summer 1994, PAUR I campaign in summer 1996, PAUR II campaign in summer 1999, MINOS campaign in summer 2001) using aircraft and surface measurements (Ziomas et al., 1998; PAUR report, 1998; Kourtidis et al., 2002; Kouvarakis et al, 2002; Traub et al., 2003; Roelofs et al., 2003). Recent continuous 3-year (1997-1999) measurements in the island of Crete agree also with the measurements presented above (Kouvarakis et al., 2000). In addition, vertical ozone summer concentrations measured in this area by ozone soundings through the whole troposphere, were above $120 \mu \mathrm{g} / \mathrm{m}^{3}$ (Varotsos et al., 1993; Varotsos et al., 1994; PAUR report, 1998).

Due to the complexity of the phenomenon of the increased tropospheric ozone levels, further research is needed for the study of the important parameters governing the formation and distribution of rural ozone in the boundary layer and the free troposphere in the south-eastern part of the European continent. Similar studies have already determined the impact of North American pollutant emissions on the rural ozone levels arriving at the Atlantic coast in Europe as well as the East Asian influence on the US Pacific coast (Parrish et al., 1993; Jacob et al., 1993; Jaffe et al., 1999). Since in Europe still few similar studies exist so far (EUROTRAC report, 1997) continuous monitoring of rural ozone and its precursors in the area is important in order to evaluate the export of ozone and its precursors from the European continent. The reason is that export of ozone and its precursors from Europe is expected to occur from the Eastern boundaries of the continent (EUROTRAC report, 1997) and the examined area is located on the most sunshine-abundant part of this boundary. According to the general circulation of air masses over southeast Europe the area surrounding Athens is under the influence of north-northeasterly flow during summer and therefore pollution influence from Eastern Europe is to be expected in the first place (Furlan, 1977). Consequently the precursor emissions in Athens are expected to influence the rural ozone levels to the south toward the Libyan coast, which is confirmed by aircraft measurements (Kallos, 1995). In any case, it is generally admitted already that large-scale reductions in the emissions of ozone precursors must take place in order to control the widespread increase of ozone in continental or global scale while a priority in the $\mathrm{NO}_{\mathrm{x}}$ reduction should be given for large-scale (regional or global) ozone control (Megie, 1996). The development of the best cost-effective scenario is not an easy task due to the accompanying socio-economic implications of any decision since many practices in the vital sectors of energy use and transportation have to be changed.

\section{Conclusions}

Based on long-term rural ozone measurements of three stations in Central Greece, Aliartos (rural), Liossia (urban peripheral) and Geoponiki (urban background) the following remarks could be made:

The diurnal variation at the remote station of Aliartos, is considerably larger than for the rural values at Liossia. This reflects the different site characteristics influencing the nocturnal physical ozone destruction to the ground. Liossia is located on a mountain slope but Aliartos in a plain where strong night inversions are observed. On the other hand there is a good agreement of the observed levels if only the afternoon values (12:00-18:00, period with the best vertical mixing and the maximum photochemistry) are compared.

In all three stations there is a clear seasonal variation of the mixing ratios of rural ozone with average summer afternoon values at about $120 \mu \mathrm{g} / \mathrm{m}^{3}$ in August and lowest winter afternoon values at about $50 \mu \mathrm{g} / \mathrm{m}^{3}$ in December-January. This implies that high summer values exist all over the area.

The fact that the secondary summer maximum in the rural ozone seasonal variation in the area is stronger than the spring maximum (very common in most northern European stations) is in favor of the hypothesis of the long-range photochemical ozone production and transport during summer, indicating a transboundary pollution problem.

For 1996 the common year of operation of the three stations a very good correlation between the rural afternoon ozone concentrations at Aliartos and the corresponding levels of Liossia and Geoponiki is observed confirming the homogenous distribution of rural ozone in the area.

It comes out that the average rural summer ozone concentrations during the afternoon remain at the same levels at about $120 \mu \mathrm{g} / \mathrm{m}^{3}$ during the 13-year period 1987-1999.

It is remarkable that in rural air the EU standard for human health protection $\left(110 \mu \mathrm{g} / \mathrm{m}^{3}, 8\right.$-hour average $)$ can be frequently exceeded during almost all the warm period of the year, (May to September) at noon and afternoon hours at all three stations examined. The 75-percentile of rural afternoon ozone during these months is constantly higher 
than $110 \mu \mathrm{g} / \mathrm{m}^{3}$. Serious violations are also observed regarding the vegetation protection standard for forests (AOT 40, $10000 \mathrm{ppbh}$ for a 6 month growing season). This level is exceeded in Aliartos by a factor of 2 and at Liossia by a factor of 3 .

It has to be noticed that the ozone levels attributed to the city activities (difference between urban and rural levels) is only a fraction of the ozone measured downwind of the urban area. For July the city-produced ozone at Liossia is about the one third and for Geoponiki about the one fourth of the afternoon ozone levels measured under southerly winds, which underlines the limits of the local efforts for the abatement of photochemical pollution.

Acknowledgements. This work was supported by the Research Committee of the Academy of Athens.

Edited by: N. Mihalopoulos

\section{References}

Bates, D.: The effects of ozone on plants and people, in: Chemistry of the Atmosphere: Its Impact on Global Change, edited by Calvert J., Blackwell Scientific Publications, pp. 239-244, 1994.

Beck, J. and Grennfeld, P.: Distribution of ozone over Europe, in: Proceedings of the EUROTRAC Symposium 92, edited by Borell, P. M., Borell, P., Cvitas, T., and Seiler, W., SPB Academic Publishing, 43-58, 1993.

Bonasoni, P., Stohl, A., Cristofanelli, P., Calzolari, F., Colombo, T., and Evangelisti, F.: Background ozone variations at the Mt. Cimone station, Atmos. Environ., 34, No. 29-30, 5183-5190, 2000.

EU Directive 92/72/EEC: Official Journal of the European Communities, No. L 297/1, 1992.

EUROTRAC report: Photo-oxidants, Acidification and Tools: Policy Application of EUROTRAC results, The report of the EUROTRAC Application Project (Volume 10), edited by Borrell, P., Builtjes, P., Grennfelt, P., and Hov, O., Springer, pp. 41-69, 1997.

Finlayson-Pitts, B. and Pitts Jr., J.: Tropospheric air pollution: Ozone, Airborne toxics, Polycyclic Aromatic Hydrocarbons, and Particles, Science, 276, 1045-1051, 1997.

Furlan, D.: The climate of southeast Europe, in: World Survey of Climatology, Vol. 6, Climates of Central and Southern Europe, edited by Wallen, C. C., Elsevier, pp. 185-224, 1977.

Glavas, S.: Surface ozone and $\mathrm{NO}_{\mathrm{x}}$ concentrations at a high altitude Mediterranean site, Greece, Atmos. Environ., 33, 38133820, 1999.

Jacob, D., Logan, J. A., Gardener, G. M., Yevich, R. M., Spivakowsky, C. M., and Wofsy, S. C.: Factors regulating ozone over the United States and its export to the global atmosphere, J. Geophys. Res., 98, 14 817-14 826, 1993.

Jaffe, D., Anderson, T., Covert, D., Kotchenruther, R., Trost, B., Danielson, J., Simpson, W., Berntsen, T., Karlsdottir, S., Blake, D., Harris, J., Carmichael, G., and Uno, I.: Transport of Asian air pollution to North America, Geophys. Res. Lett., 26, No. 6, $711,1999$.
Kalabokas, P. D., Amanatidis, G. T., and Bartzis, J. G.: Rural ozone levels at an Eastern Mediterranean site (Attica, Greece), in: Proceedings of the XVIII Quadrennial Ozone Symposium, edited by Bojkov, R. and Visconti, G., L' Aquila, Italy, pp. 379-382, 1996.

Kalabokas, P. D. and Bartzis, J. G.: Photochemical air pollution characteristics at the station of the NCSR-Demokritos, during the MEDCAPHOT-TRACE campaign, Greece (August 20thSeptember 20th, 1994), Atmos. Environ., 32, 12, 2123-2139, 1998.

Kalabokas, P. D, Viras, L. G., and Repapis, C. C.: Analysis of the 11-year record (1987-1997) of air pollution measurements in Athens, Greece. Part I: Primary pollutants, Global Nest: The International Journal, 1, No. 3, 157-168, 1999a.

Kalabokas, P. D., Viras, L. G., Repapis, C. C., and Bartzis, J. G.: Analysis of the 11-year record (1987-1997) of air pollution measurements in Athens, Greece. Part II: Photochemical pollutants, Global Nest: The International Journal, 1, No. 3, 169-176, 1999b.

Kalabokas, P. D., Viras L. G., Bartzis J. G., and Repapis C. C.: Mediterranean rural ozone characteristics around the urban area of Athens, Atmos. Environ., 34, No. 29-30, 5199-5208, 2000.

Kalabokas, P. D.: Surface Ozone Characteristics at the Periphery of the Urban Area of Athens, Greece, in: Proceedings of the 8th European Symposium on Physicochemical Behaviour of atmospheric pollutants (on CD-ROM), September 2001, Torino, Italy, 2001.

Kallos, G.: Transport and transformation of air pollutants from Europe to the east Mediterranean region, Progress report, contract AVI-CT92-0005, Eur. Comm. Environ. Res. Programme Avicenne, Brussels, 1995.

Kley, D., Geiss, H., and Mohnen, V.: Tropospheric ozone at elevated sites and precursor emissions in the United States and Europe, Atmos. Environ., 28, 149-158, 1994.

Kourtidis, K., Ziomas, I., Zerefos, C., Balis, D., Suppan, P., Vassaras, A., Kosmidis, V., and Kentrarchos, A.: On the background ozone values in Greece, 7th European Symposium on Physico-chemical Behaviour of Atmospheric Pollutants: The oxidizing capacity of the Troposphere, EUR 17482 EN, pp. 456461, Venice, Italy, 1996.

Kourtidis, K., Zerefos, C., Rapsomanikis, S., Simeonov, V., Balis, D., Perros, P. E., Thomson A. M., Witte, J., Calpini, B., Sharobiem, W. M., Papayiannis, A., Mihalopoulos, N., and Drakou, R.: Regional levels of ozone in the troposphere over eastern Mediterranean, J. Geophys. Res., 107(D18), 8140, doi:10.1029/2000JD000140, 2002.

Kouvarakis, G., Tsigaridis, K., Kanakidou, M., and Mihalopoulos, N.: Temporal variations of surface regional background ozone over Crete Island in the southeast Mediterranean, J. Geophys. Res., 105, D4, 4399-4407, 2000.

Kouvarakis, G., Vrekoussis, M., Mihalopoulos, N., Kourtidis, K., Rappenglueck, B., Gerasopoulos, E., and Zerefos, C.: Spatial and temporal variability of tropospheric ozone in the boundary layer above the Aegean Sea (eastern Mediterranean), J. Geophys. Res., 107(D18), 8137, doi:10.1029/2000JD000081, 2002.

Megie, G.: Ozone and oxidant properties of the troposphere (in French), La Meteorologie, 13 (8e serie), 11-28, 1996.

Millan, M. M., Artinano, B., Alonso, L., Castro, M., FernandezPatier, R., and Goberna, J.: Mesometeorological cycles of air pollution in the Iberian Peninsula, CEC-DGXII Air Pollution Re- 
search Report 44, Contract EV4V-0097E, Brussels, 1992.

MinEnv report.: Atmospheric pollution in Athens - 1999, Directorate of air pollution and noise control, Ministry of Environment (in Greek), 2000.

Parrish, D. D., Holloway, J. S., Trainer, M., Murphy, P. C., Forbes, G. L., and Fehsenfeld, F. C.: Export of North American ozone pollution to the North Atlantic Ocean, Science, 259, 1436-1439, 1993.

PAUR report: Photochemical Activity and Solar Ultraviolet Radiation (PAUR), Environment Program, Contract No. ENV4-CT950048, EU-DGXII, 1998.

PORG report: UK Photochemical Oxidants Review group, Department of the Environment, London, 1997.

Repapis, C., Zerefos, C., and Tritakis, B.: On the Etesians over the Aegean, Proc. Acad. Athens, 52, 572-606, 1977.

Roelofs, G. J., Scheeren, H. A., Heland, J., Ziereis, H., and Lelieveld, J.: A model study of ozone in the eastern Mediterranean free troposphere during MINOS (August 2001), Atmos. Chem. Phys. 3, 1199-1210, 2003.

Scheel H. E., Areskoug, H., Geiß, H., Gomiscek, B., Granby, K., Haszpra, H., Klasinc, L., Kley, D., Laurila, T., Lindskog, A., Roemer, M., Schmitt, R., Simmonds, P., Solberg, S., and Toupance, G.: On the spatial distribution and seasonal variation of lower-troposphere ozone over Europe, J. Atmos. Chem, 28, 11-28, 1997.
Traub, M., Fisher, H., de Reus, M., Kormann, R., Heland, J., Ziereis, H., Schlager, H., Holzinger, R., Williams, J., Warnecke, C., de Gouw, J., and Lelieveld, J.: Chemical characteristics assigned to trajectory clusters during the MINOS campaign, Atmos. Chem. Phys. 3, 459-468, 2003.

Varotsos, C., Kalabokas, P., and Chronopoulos, G.: Atmospheric ozone concentration at Athens, Greece, Part II: Vertical ozone distribution in the troposphere, Atmos. Res., 30, 151-155, 1993.

Varotsos, C., Chronopoulos, G., Kalabokas, P.: Seasonal variation and cross tropopause ozone exchange at Athens, Greece, in: Proccedings of the 3rd EUROTRAC Symposium-Photooxidants: Precursors and products, pp. 305-309, April 1994, GarmishPartenkirchen, Germany, 1994.

Volz, A. and Kley, D.: Evaluation of the Montsouris series of ozone measurements made in the nineteenth century, Nature, 332, 240 242, 1988.

Ziomas, I.: The Mediterranean Campaign of Photochemical Tracers-Transport and Chemical Evolution (MEDCAPHOTTRACE): An outline, Atmos. Environ., 32, 2045-2054, 1998.

Ziomas, I. C., Tzoumaka, P., Balis, D., Melas, D., Zerefos, C. S., and Klemm, O.: Ozone episodes in Athens, Greece, A modelling approach using data from the MEDCAPHOT-TRACE, Atmos. Environ., 32, 2313-2322, 1998. 